\title{
ÚLOHA EVROPSKÉHO PARLAMENTU PŘI PROSAZOVÁNÍ LIDSKÝCH PRÁV VE SPOLEČNÉ OBCHODNÍ POLITICE EU*
}

\author{
ONDŘEJ SVOBODA
}

\begin{abstract}
The Role of the European Parliament in the Promotion of Human Rights in the EU Common Commercial Policy

The Common commercial policy of the European Union has been changing its nature after the adoption of the Lisbon Treaty as the protection of human rights is today its important dimension. There are several reasons for this development and the expanding role of the European Parliament is undoubtedly one of them. This article aims to assess and demonstrate the European Parliament's role on the basis of several specific case-studies in the area of negotiations of free trade agreements, the Generalised System of Preferences, and the debate on responsible business conduct of multinational enterprises. It comes to the conclusion that the European Parliament has become an influential actor in the Common commercial policy advocating for the use of trade instruments to promote human rights abroad.
\end{abstract}

Keywords: common commercial policy; European Union; European Parliament; human rights; generalised system of preferences; free trade agreements

Klíčová slova: společná obchodní politika; Evropská unie; Evropský parlament; lidská práva; všeobecný systém preferencí; dohody o volném obchodu

DOI: $10.14712 / 23366478.2021 .2$

\section{1. ÚVOD}

V souvislosti se společnou obchodní politikou Evropské unie není pravděpodobně první věcí, která člověka napadne, otázka lidských práv. Jsou to však právě lidská práva a jejich ochrana, které jsou stále častěji $\mathrm{v}$ této důležité oblasti unijních aktivit akcentovány i s ohledem na dlouhou tradici prosazování politických hodnot včetně lidských práv unijními obchodněpolitickými nástroji, tradici, která sahá nejméně k Dohodě z Lomé z roku $1989^{1}$ a která byla zobecněna v roce 1995 na všechna obchodní vyjednávání EU. ${ }^{2}$ Důvodů ke stále rostoucímu zájmu je několik. Od změn v evropském právu uvedených Lisabonskou smlouvou v roce 2009 a následným vstupem nových aktérů, především Evropského parlamentu (dále také jen „EP“), kteří obchodní politiku

\footnotetext{
* Text byl zpracován v rámci programu Právnické fakulty Univerzity Karlovy Výzkumné centrum pro lidská práva, UNCE č. UNCE/HUM/011.

1 Dohoda z Lomé IV, 15. prosince 1989 [1991] OJ L229/3, čl. 5 odst. 2. Blíže k této úpravě viz REID, E. Balancing Human Rights, Environmental Protection and International Trade: Lessons from the EU Experience. London: Hart Publishing, 2015, s. 148-150.

2 Rada EU. Council Conclusions of 29 May 1995, reported in EU Bulletin 1995-5, b. 1.2.3.
} 
ovlivňují, až po zvýšený zájem evropské veřejnosti i parlamentů členských států o témata mezinárodního obchodu.

V rovině primárního práva EU je nově obchodní politika od přijetí Lisabonské smlouvy rovněž používána jako nástroj pro prosazování evropských zásad a hodnot jakožto součást širšího vystupování Unie navenek. Právo EU totiž ukládá Unii podporovat a prosazovat základní hodnoty jako jsou lidská práva, demokracie, ochrana životního prostředí apod. ve vnějších vztazích Evropské unie. Zatímco čl. 3 odst. 5 Smlouvy o Evropské unii (SEU) stanovuje ve vnějších vztazích Evropské unie s okolním světem přispívat $\mathrm{k}$ ochraně lidských práv, především práv dítěte, a k přísnému dodržování a k rozvoji mezinárodního práva, v čl. 21 odst. 1 SEU se uvádí, že: ,, [č]innost Unie na mezinárodni scéně spočivá na zásadách, které se uplatnily při jejím založení, jejím rozvoji a jejím rozšiřováni a které hodlá podporovat v ostatním světě: demokracie, právní stát, univerzálnost a nedèlitelnost lidských práv a základních svobod, úcta k lidské di̊stojnosti, zásady rovnosti a solidarity a dodržování zásad Charty Organizace spojených národi̊ a mezinárodního práva ". ${ }^{3}$ Společná obchodní politika tak již nesleduje pouze otevírání zahraničních trhů a související snahy o liberalizaci mezinárodního obchodu, ale od roku 2009 se musí rídit také těmito obecnými zásadami. ${ }^{4}$

Další podstatná charakteristika obchodní politiky tkví v tom, že v ní má EU výlučné pravomoci. ${ }^{5}$ To znamená, že za obvyklých okolností o její tvorbě a uplatňování rozhodují primárně orgány EU, a ne členské státy, které mohou v této oblasti jednat pouze na základně zmocnění, nebo při provádění unijních aktů. ${ }^{6}$ Je to právě činnost Evropského parlamentu, který zdůrazñuje tuto významnou změnu obsaženou v Lisabonské smlouvě, kdy jsou poprvé vnější politiky EU a její cíle úzce propojeny s obchodní politikou. ${ }^{7}$ EP již v roce 2010 konstatoval, že ,obchodní politika není samoúčelná “ a „,moderní obchodní politika musí zohlednit jiné oblasti politik, jako jsou: a) lidská práva, [...], c) pracovni práva a hlavni pracovni normy Mezinárodni organizace práce, d) sociální odpovědnost podniků [...] “. ${ }^{8} \mathrm{~K}$ tomu využívá svoji vlastní posílenou pozici v rámci institucionálního uspořádání Unie, v němž je nejaktivnější unijní institucí vystupující proti porušování lidských práv. ${ }^{9}$

3 Blíže BARTELS, L. The EU's Human Rights Obligations in Relation to Policies with Extraterritorial Effects. European Journal of International Law. 2015, Vol. 25, No. 4, s. 1 071-1 091.

4 Čl. 205 Smlouvy o fungování Evropské unie (SFEU). Konkrétně viz např. CREMONA, M. Structural Principles and their Role in EU External Relations Law. Current Legal Problems. 2016, Vol. 69, No. 1, s. 35-66.

5 Čl. 3 SEU. Blíže LEAL-ARCAS, R. EU Trade Law. Cheltenham: Edward Elgar Publishing, 2019, s. 87-92; nebo k nedávným kompetenčním sporům v obchodní politice SVOBODA, O. Změny společné obchodní politiky po stanovisku Soudního dvora EU k dohodě o volném obchodu EU-Singapur. Acta Universitatis Carolinae Iuridica. 2019, Vol. LXV, č. 2, 2019, s. 91-102.

6 KRAJEWSKI, M. The Reform of the Common Commercial Policy. In: BIONDI, A. - EECKHOUT, P. RIPLEY, S. (eds.). EU Law After Lisbon. Oxford: Oxford University Press, 2012, s. 298-299.

7 BENDINI, R. In-depth Analysis: the European Union's trade policy, five years after the Lisbon Treaty. European Parliament's Directorate-General for External Policies, DG EXPO/B/PolDep/Note/2014 76, 2014, s. 9.

8 Usnesení Evropského parlamentu ze dne 27. záŕí 2011 o nové obchodní politice pro Evropu v rámci strategie Evropa 2020 (2010/2152(INI)), odst. 5.

9 GEOFFREY, H. The Role of the European Parliament in Human Rights Protection. In: BENEDEK, W. KARL, W. et al. (eds.). European Yearbook on Human Rights. Vienna: Intersentia, 2009, s. 109. 
Tento př́spěvek má za cíl zodpovědět, jak velkou roli v prosazování roviny lidských práv do obchodní politiky EU hraje Evropský parlament, v jakých konkrétních oblastech a jakými způsoby. Nejdříve bude proto stručně představeno institucionální zakotvení Evropského parlamentu při tvorbě obchodní politiky a jeho pravomoci. Následně budou diskutovány jednotlivé oblasti, ve kterých je EP zvláště aktivní a které jsou určující pro vztah společné obchodní politiky lidských práv. Jedná se zejména o obsah unijních obchodních a investičních dohod, Všeobecný systém preferencí (GSP) a oblast odpovědného obchodního chování podniků, resp. byznysu a lidských práv. Analýza těchto př́padů potvrdí rostoucí vliv Evropského parlamentu na podobu společné obchodní politiky Unie, která se mj. promítá i do posilování její lidskoprávní roviny.

\section{INSTITUCIONÁLNÍ ROLE EVROPSKÉHO PARLAMENTU VE SPOLEČNÉ OBCHODNÍ POLITICE}

Jednou z nejzásadnějších změn v polisabonské obchodní politice Unie je institucionální posílení pozice Evropského parlamentu, které má zajistit její větší demokratickou legitimitu. ${ }^{10}$ To EP umožňuje prosazovat zvýšenou pozornost jeho prioritám, včetně ochrany lidských práv, v zahraničněpolitických, rozvojových i obchodních nástrojích Unie vis-à-vis dalším unijním institucím, především Radě EU a Evropské komisi (dále také jen „EK“). K tomu disponuje Evropský parlament širokou paletou nástrojů.

Evropský parlament je $\mathrm{v}$ první řadě nově spolunormotvůrce unijních právních předpisů v oblasti obchodní politiky, ${ }^{11}$ čímž je přímo zapojen do formulování unijní obchodní politiky. Jedná se např. o unijní legislativu týkající se ochranných doložek a dalších mechanismů, které umožňují dočasné odnětí preferencí v některých obchodních dohodách, nebo Všeobecného systému preferencí.

Evropský parlament také získal klíčovou roli při schvalování mezinárodních smluv uzavíraných Unií, kdy musí s jejich uzavřením vyslovit souhlas. ${ }^{12}$ Naplno se nově nabytá pravomoc projevila $v$ prŕípadě Obchodní dohody proti padělatelství (ACTA). Tato obchodní dohoda měla vést $\mathrm{k}$ vytvoření mezinárodního systému pro vynucování práv duševního vlastnictví. Nicméně v červenci 2012 Evropský parlament v plenárním zasedání dohodu zamítl a fakticky ji tak celou pohřbil. ${ }^{13}$ Podstatná část výhrad europoslanců byla přitom v diskuzi $\mathrm{k}$ dohodě založena na obavách o ochranu lidských práv. ${ }^{14}$ Toto

10 WOOLCOCK, S. EU Trade and Investment Policymaking After the Lisbon Treaty. Intereconomics. 2010, Vol. 45, No. 1, s. 23.

11 Čl. 207 odst. 3 SFEU.

12 KRAJEWSKI, c. d., s. 308-310; KADDOUS, C. The Transformation of the EU Common Commercial Policy. In: EECKHOUT, P. - LOPEZ-ESCUDERO, M. (eds.). The European Union's External Action in Times of Crisis. Oxford: Hart Publishing, 2016, s. 444-448.

13 Legislativní usnesení Evropského parlamentu ze dne 4. července 2012 k návrhu rozhodnutí Rady o uzavření Obchodní dohody proti padělatelství mezi Evropskou unií a jejími členskými státy, Austrálií, Kanadou, Japonskem, Korejskou republikou, Spojenými státy mexickými, Marockým královstvím, Novým Zélandem, Singapurskou republikou, Švýcarskou konfederací a Spojenými státy americkými (12195/2011 - C7-0027/2012 - 2011/0167(NLE)).

14 BEKE, L. - D'HOLLANDER, D. - HACHEZ, N. - PÉREZ, B. Report on the integration of human rights in EU development and trade policies. 30. záŕí 2014, s. 27. 
právo veta, kterým EP disponuje nad každou dojednanou obchodní nebo investiční dohodou Unie, posílilo pravděpodobně postavení Evropského parlamentu nejvíce. ${ }^{15}$

V tomto kontextu je také důležitá méně formalizovaná role EP ve fázi zahájení jednání o obchodních a investičních dohodách. Je logické, že Evropská komise dobrovolně upřednostní projednání východisek a cílů mezinárodních vyjednávání s europoslanci, aby se mohla vyhnout př́padnému zmiňovanému nesouhlasu s dohodou v pozdější fázi schvalování. ${ }^{16} \mathrm{~V}$ praxi tak může EP požadovat od Evropské komise větší tlak na vyjednávacího partnera, aby zlepšil své domácí lidskoprávní podmínky, jinak nedá dohodě nezbytný souhlas.

Př́ikladů použití této pravomoci v souvislosti s ochranou lidských práv je v průběhu posledních let několik. V roce 2011 např. EP pozastavil uzavření Protokolu o textilních výrobcích k Dohodě o partnerství a spolupráci mezi EU a Uzbekistánem zejména z důvodu pochybností týkajících se dětské práce. Svůj souhlas s uzavřením protokolu udělil až v roce 2016 poté, co došlo v této oblasti ze strany Uzbekistánu k významnému zlepšení, včetně přijetí právních předpisů, které zakazují dětskou práci. ${ }^{17}$ Dalším př́íkladem je obchodní dohoda mezi EU a Kolumbií a Peru, kdy před jejím schválením EP vyjádřil výhrady k ochraně lidských, environmentálních a pracovních práv v Kolumbii. ${ }^{18}$ Kolumbie následně předložila plán ke zlepšení situace a EP vyslovil souhlas s uzavřením dohody. Obdobná situace nastala v př́padě dohody o volném obchodu s Vietnamem. Europoslanci opakovaně v průběhu vyjednávání upozorňovali na propojení dojednané dohody s lidskými právy a vyzvali Vietnam ke zlepšení situace, zvláště v oblasti politických a pracovních práv. ${ }^{19}$ Přestože bude snaha po volbách do Evropského parlamentu získat jeho souhlas s dlouho odkládanou dohodou co nejdříve, je možné, že její ratifikace se opět oddálí, pokud noví europoslanci vyhodnotí dodržování lidských práv ve Vietnamu jako neuspokojivé.

Evropský parlament má dále kontrolní roli nad prováděním obchodní politiky. ${ }^{20}$ Evropská komise je vázána pravidelně podávat zprávu o pokroku těchto jednání s třetími zeměmi nebo mezinárodními organizacemi. ${ }^{21} \mathrm{~V}$ rámci parlamentních struktur je

15 RICHARDSON, L. The Post-Lisbon Role of the European Parliament in the EU's Common Commercial Policy: Implications for Bilateral Trade Negotiations. EU Diplomacy Papers. 2012, No. 5, s. 5.

16 ŠTĚRBOVÁ, L. Lisabonská smlouva a společná obchodní politika EU. Současná Evropa. 2010, č. 2, s. $36-37$.

17 Nelegislativní usnesení Evropského parlamentu ze dne 14. prosince 2016 o návrhu rozhodnutí Rady o uzavření protokolu k Dohodě o partnerství a spolupráci, kterou se zakládá partnerství mezi Evropskými společenstvími a jejich členskými státy na straně jedné a Republikou Uzbekistán na straně druhé, kterým se mění dohoda s cílem rozšírit její působnost na dvoustranný obchod s textilními výrobky, s přihlédnutím k pozbytí platnosti dvoustranné dohody o textilních výrobcích (16384/1/2010 - C7-0097/2011 2010/0323(NLE) - 2016/2226(INI)).

18 Usnesení Evropského parlamentu ze dne 13. června 2012 o Obchodní dohodě mezi EU a Kolumbií a Peru (2012/2628(RSP)), odst. 15.

19 Usnesení Evropského parlamentu ze dne 15. listopadu 2018 o Vietnamu, zejména o situaci politických vězño (2018/2925(RSP)).

20 LOEWENTHAL, J.-P. Articles 13-18. In: KELLERBAUER, M. - KLAMERT, M. - TOMKIN, J. (eds.). The EU Treaties and the Charter of Fundamental Rights: a Commentary. Oxford: Oxford University Press, 2019, s. 136-138.

21 Čl. 207 odst. 3 SFEU; čl. 218 odst. 6(a)(v) SFEU. Pro bližší rozbor viz např. SIMOES, F. D. The European Parliament's Oversight Powers Over Trade and Investment Negotiations. European Investment Law and Arbitration Review. 2017, Vol. 2, s. 346-350. 
to Výbor pro mezinárodní obchod (INTA), který má ústřední roli v parlamentní kontrole obchodní politiky Unie. ${ }^{22}$ Informační povinnost je odražena v interinstitucionální rámcové dohodě mezi Evropskou komisí a Evropským parlamentem, která zavazuje EK informovat Výbor INTA o všech fázích vyjednávání o obchodních a investičních dohodách, včetně jejich přípravné fáze. ${ }^{23}$

Často opomíjenou, přesto také důležitou aktivitou, je parlamentní diplomacie, kdy se delegace Evropského parlamentu účastní různých mezinárodních jednání k obchodněpolitickým tématům, nebo se jedná o cesty europoslanců do vybraných zemí, se kterými EU vyjednává obchodní a investiční dohody. Konkrétním příkladem je aktivní vystupování na výroční parlamentní konferenci Světové obchodní organizace (WTO), kde zástupci Evropského parlamentu pravidelně upozorňují na problematiku udržitelného rozvoje a lidská práva. ${ }^{24} \mathrm{Z}$ poslední doby je možné uvést př́iklad, kdy parlamentní delegace zrušila plánovanou cestu do Myanmaru. Tam měla zjistit dopady dohody o ochraně investic, u které se Unie s Myanmarem dohodla již na téměř celém textu a měla být brzy podepsána. Nicméně kvůli zhoršující se lidskoprávní situaci v zemi byla cesta zrušena, čímž se pravděpodobně oddálilo i sjednání samotné investiční dohody, kdy EP vyzval $\mathrm{k}$,opatrnosti““ ohledně jejího uzavření. ${ }^{25}$

V neposlední řadě může Evropský parlament využít své rozpočtové pravomoci podle článku 14 SEU a čl. 310 odst. 1 SFEU a ovlivnit přidělování finančních prostředků na unijní nástroje používané při prosazování lidských práv ve třetích zemích. ${ }^{26}$

V právní rovině je pak nepochybně potencionálně významná i legitimace obracet se na SDEU o posudek ohledně souladu zamýšlené mezinárodní dohody se zakládacími smlouvami podle čl. 218 odst. 11 SFEU. S jejím využitím může EP potencionálně dosáhnout judicializace problémů týkajících se dodržování lidských práv s ohledem na uzavírání mezinárodních smluv a získat ve formě závazného posudku SDEU silný nástroj k ovlivnění jejich obsahu.

\section{OBSAH UNIJNÍCH OBCHODNÍCH A INVESTIČNÍCH DOHOD}

Obchodní a investiční dohody, které sjednává Evropská unie, patří k základním nástrojům společné obchodní politiky. Evropský parlament využívá svého posíleného postavení a má na jejich podobu rostoucí vliv, ${ }^{27}$ který se snaží promítnout i do posílení lidskoprávní dimenze těchto dohod.

Počáteční snahy EP se soustředily na prosazování tzv. doložky o lidských právech (human rights clause / human rights conditionality). Již od poloviny 90. let minulého

22 V otázkách spojenými s lidskými právy pak spolupracuje s Podvýborem pro lidská práva (DROI).

23 Rámcová dohoda o vztazích mezi Evropským parlamentem a Evropskou komisí. Úřední věstník EU L 304/47, 20. listopadu 2010, odst. 23.

24 Viz např. SCHOLZ, H. What future for the WTO? Making Trade Work for Development After Nairobi: discussion paper for the 2016 Annual Session of the Parliamentary Conference on the WTO, PC-WTO/2016/R.3, 27. května 2016.

25 Usnesení Evropského parlamentu ze dne 7. července 2016 o Myanmaru, zejména o situaci Rohingyů (2016/2809(RSP)), odst. 19.

26 LOEWENTHAL, c. d., s. 136-138.

27 LEAL-ARCAS, c. d., s. 224. 
století tak existuje současný politický rámec, na základě kterého Unie prosazuje tuto doložku jako součást mezinárodních smluv mezi EU a třetími zeměmi nebo regionálními organizacemi, včetně obchodních dohod. Jedná se o ustanovení, které obvykle definuje dodržování lidských práv jako ,základní prvek“ těchto dohod a není-li řádně dodržováno, mohou být v souladu s dohodou uplatněna různá opatření, např̀. omezení nebo pozastavení výhod plynoucích z dohody. ${ }^{28}$ Takové rozhodnutí nicméně záleží na Evropské komisi, v jejímž rozhodování hrají nakonec velkou roli i úvahy nad politickými dopady aktivace doložky. ${ }^{29}$

Že je zahrnování doložek o lidských právech dlouhodobou prioritou Evropského parlamentu, potvrzují jeho pravidelná stanoviska na toto téma. Např. v roce 2005 vydal usnesení o doložce o lidských právech a demokracii v dohodách Evropské unie, kde se věnoval mj. i obchodním dohodám. ${ }^{30}$ Později v roce 2015 ve zprávě o dopadu finanční a hospodářské krize na lidská práva požadoval Evropský parlament záruky řádného sledování a praktické uplatňování doložky o lidských právech v rámci každé obchodní dohody. ${ }^{31}$ Naposledy byla důležitost podmíněnosti lidských práv v obchodních dohodách připomenuta ve výroční zprávě Evropského parlamentu stejně jako nezbytná podpora demokratických systémů a snahy o svobodu národů, které by měly být nadále hlavními zásadami, jimiž se hospodářské zájmy EU rrídí. ${ }^{32}$ Nutno podotknout, že prosazování lidských práv je vnímáno jako širší cíl vnější akce EU ze strany všech hlavních orgánů EU.33

Kromě lidskoprávní doložky se Evropský parlament snaží prosazovat systematické zařazování sociálních a environmentálních norem, včetně základních úmluv Mezinárodní organizace práce (MOP) a lidskoprávních úmluv jako Úmluvy o zabránění a trestání zločinu genocidy, Mezinárodního paktu o občanských a politických právech, Mezinárodního paktu o hospodářských, sociálních a kulturních právech, Úmluvy o právech dítěte nebo Mezinárodní úmluvy o odstranění všech forem rasové diskriminace. ${ }^{34}$

Tyto normy by také měly být podle názoru EP doprovázeny efektivním nezávislým mechanismem řešení sporů, včetně efektivního vymáhání a dodržování závazků v oblasti

28 Bliže viz BARTELS, L. The European Parliament's role in relation to human rights in trade and investment agreements. Policy European Parliament, Department DG External Policies EXPO/B/DROI/2012-09, 2014; VELLUTI, S. The Promotion and Integration of Human Rights in EU External Trade Relations. Utrecht Journal of International and European Law. 2016, Vol. 32, No. 83, s. 53-57; ZAMFIR, I. Human Rights in EU Trade Agreements: the Human Rights Clause and its Application. European Parliamentary Research Service, PE 637.975, 2019.

29 REID, c. d., s. 172-173.

30 Usnesení Evropského parlamentu ze dne 14. února 2006 o doložce o lidských právech a demokracii v dohodách Evropské unie (2005/2057(INI)).

31 Usnesení Evropského parlamentu ze dne 18. dubna 2013 o dopadu finanční a hospodářské krize na lidská práva (2012/2136(INI)). O zprávě také informovalo Výzkumné centrum pro lidská práva v r. 2013, viz ONDŘEJEK, P. Podvýbor pro lidská práva Evropského parlamentu projednal Zprávu o dopadu finanční a hospodářské krize na lidská práva. In: Výzkumné centrum pro lidská práva [online]. 31. 1. 2013 [cit. 202009-29]. Dostupné na: https://www.vclp.cz/news/podvybor-pro-lidska-prava-evropskeho-parlamentu -projednal-zpravu-o-dopadu-financni-a-hospodarske-krize-na-lidska-prava/.

32 Usnesení Evropského parlamentu ze dne 12. prosince 2018 o výroční zprávě o stavu lidských práv a demokracie ve světě v roce 2017 a o politice Evropské unie v této oblasti (2018/2098(INI)), odst. 50.

33 Viz např. Rada EU. Conclusions of 20 July 2015 on the Action Plan on Human Rights and Democracy 2015-2019, 20. července 2015. Zde se výslovně požaduje vkládání lidskoprávních doložek do mezinárodních dohod EU.

34 Usnesení Evropského parlamentu ze dne 25. listopadu 2010 o lidských právech, sociálních a environmentálních normách v mezinárodních obchodních dohodách (2009/2219(INI)), odst. 15. 
lidských práv, a větším zapojením občanské společnosti. ${ }^{35}$ Tento soustavný tlak pravděpodobně také přispěl k rozsáhlé konzultaci o zlepšení implementace kapitol dohod o volném obchodu a udržitelném rozvoji, kterou provedla Evropská komise s dalšími evropskými institucemi a zapojenými stranami (stakeholdery) v letech 2017 a 2018. ${ }^{36}$ V př́padě formulování investiční politiky Unie Evropský parlament již ve svém prvním stanovisku k úvodním představám EK o investiční politice Unie vyslovil požadavek, aby budoucí unijní investiční dohody zavazovaly investory k dodržování lidských práv. ${ }^{37}$

Tyto požadavky EP opakuje v různých formách u konkrétních vyjednávání, ${ }^{38}$ čímž vyvíjí soustavný tlak, aby se tímto tématem Rada a Evropská komise zabývaly. ${ }^{39}$ Evropský parlament připomíná potřebu zohledňování lidských práv i ve vyjednáváních s tak obtížnými partnery jako je Č́na. Při zahájení vyjednávání o investiční dohodě mezi EU a Čínou zdůraznil, že ,,investiční dohody, které EU uzavře, nesmí být v rozporu se základními hodnotami, o jejichž prosazováni EU v rámci své vnějši politiky usiluje, a proto nesmi oslabovat možnost veřejných zásahủ, zejména při sledování cílủ veřejných politik, jako jsou sociálni a environmentálni kritéria, lidská práva, boj proti padělání a dále bezpečnost, práva zaměstnancư a spotřebitelů [...]".40 Lidskoprávní doložky jsou ale požadovány i u partnerů, u kterých jsou malé pochybnosti o jejich právních systémech. V minulosti podobné snahy vůči Austrálii a Novému Zélandu dokonce vedly k přerušení rozhovorů mezi oběma stranami. Zůstává tak na vyjednavačích Evropské komise, nakolik se ambiciózní prání europoslanců podaří v praxi prosadit.

\section{VŠEOBECNÝ SYSTÉM CELNÍCH PREFERENCÍ}

Všeobecný systém celních preferencí je jednostranný obchodní nástroj EU, kterým poskytuje rozvojovým zemím a územím jednostranně zvýhodněný př́stup na jednotný trh, aby „,podpořil udržitelný hospodářský a sociální rozvoj a rozvoj v oblasti

35 Tamtéž, odst. 22. Dále také Usnesení Evropského parlamentu ze dne 5. července 2016 k nové a inovativní budoucí strategii pro obchod a investice (2015/2105(INI)), odst. 18-19.

36 Evropská komise. Trade and Sustainable Development (TSD) chapters in EU Free Trade Agreements (FTAs), 11. července 2017; Evropská komise. Feedback and way forward on improving implementation and enforcement of Trade and Sustainable Development chapters in EU Free Trade Agreements, 26. února 2018. Bliže HRADILOVÁ, K. - SVOBODA, O. Sustainable Development Chapters in the EU Free Trade Agreements: Searching for Effectiveness. Journal of World Trade. 2018, Vol. 52, No. 6, s. 1 028-1 032.

37 Usnesení Evropského parlamentu ze dne 6. dubna 2011 o budoucí evropské mezinárodní investiční politice (2010/2203(INI)), odst. 37.

38 Např. Usnesení Evropského parlamentu ze dne 9. ř́jna 2013 o jednáních mezi EU a Čínou o dvoustranné investiční dohodě (2013/2674(RSP)), odst. 33; Usnesení Evropského parlamentu ze dne 25. února 2016 o zahájení jednání o dohodě o volném obchodu s Austrálií a Novým Zélandem (2015/2932(RSP)), odst. 8; Doporučení Evropského parlamentu ze dne 14. září 2017 Radě, Komisi a Evropské službě pro vnější činnost k jednáním o modernizaci obchodního pilíře dohody o přidružení EU-Chile (2017/2057(INI)), odst. 1(u).

39 Generální ředitelství pro obchod EK mělo projít i částečnou vnitřní reorganizací v roce 2011, aby dokázalo lépe reagovat na vzrůstající lidskoprávní požadavky ze strany EP. Viz BENOIT-ROHMER, F. et al. Human Rights Mainstreaming in EU's External Relations, European Parliament Directorate-General for External Policies of the Union. EXPO/B/DROI/2008/66, 2009, s. 15.

40 Usnesení Evropského parlamentu ze dne 9. ř́jna 2013 o jednáních mezi EU a Čínou o dvoustranné investiční dohodě (2013/2674(RSP)), odst. 23. 
životniho prostředí v rozvojových zemích, přičemž hlavním cílem je vymýcení chudoby “" ${ }^{41}$ Součástí společné obchodní politiky je od roku 1971. Ačkoliv jsou reálné pozitivní dopady na rozvojové země sporné, ${ }^{42}$ patří mezi základní unijní obchodní nástroje s rozvojovým rozměrem. Jeho poslední podoba je upravena nařízením Evropského parlamentu a Rady (EU) č. 978/2012. Tento předpis byl přijat řádným legislativním postupem a Evropský parlament jej tak projednával poprvé v roli spolunormotvůrce.

Součástí stávajícího systému je zvláštní pobídkový režim pro udržitelný rozvoj a řádnou správu věcí veřejných (GSP+), v jehož rámci se rozvojové země zavazují k ratifikaci a účinnému provádění základních mezinárodních úmluv o lidských a pracovních právech, ochraně životního prostředí apod. $V$ případě, že se tak neděje, může Evropská komise rozhodnout o pozastavení, nebo ukončení výhod.

$\mathrm{K}$ dočasnému pozastavení preferencí GSP+ došlo např. v únoru 2010 vůči Srí Lance poté, co Evropská komise zjistila nedostatky v implementaci tř́ lidskoprávních úmluv OSN. Jednalo se však o spíše ojedinělý př́pad, kdy se Evropská komise rozhodla k takovému kroku. Evropský parlament vyzývá Evropskou komisi k tomuto kroku mnohem častěji, než kdy je EK ochotná k němu přistoupit. V poslední době např. Evropský parlament vyzval Evropskou komisi, aby „, využila všech dostupných nástrojů $\mathrm{k}$ tomu, aby přesvědčila Filipíny, aby učinily přitrž popravám bez řádného soudu v souvislosti s tažením proti drogám, a pokud se v přištich několika měsicich situace nijak zásadně nezlepší, aby také učinila procesni kroky k prípadnému zrušení výhod v rámci systému $G S P+" .43$

Pro Evropský parlament zůstává obchodní systém GSP+ ,jedním z hlavních nástrojů obchodni politiky EU k prosazování demokracie, lidských práv, udržitelného rozvoje a norem ochrany životního prostředí ve vztahu k třetím zemím " 44 a ,klíčovým nástrojem obchodni politiky EU, který poskytuje lepši přistup na trh a je doplněn striktním monitorovacím mechanismem s cílem prosazovat lidská a pracovní práva, ochranu životního prostředí a řádnou správu věcí verejných v rozvojových zemích ve zranitelném postaveni " ${ }^{45}$ Dlouhodobě proto věnuje pozornost nejen konkrétním případům, kdy je v jednotlivých zemích neuspokojivá situace v dodržování lidských práv, ale snaží se i o systémové zlepšení jeho účinnosti. Opakovaně tak vyzývá Evropskou komisi, aby systémy GSP+ důsledněji monitorovala a zajistila tak dodržování norem v oblasti lidských práv ze strany príijímajících zemí. V tomto ohledu také EP vyzval k přijetí jasných

41 Nařízení Evropského parlamentu a Rady (EU) č. 978/2012 ze dne 25. ř́jna 2012 o uplatňování systému všeobecných celních preferencí a o zrušení nařízení Rady (ES) č. 732/2008, odst. 3.

42 Např. CUYVERS, L. - SOENG, R. The impact of the EU Generalized System of Preferences on exports and GSP utilization by Asian and Latin American countries. Journal of International Trade Law and Policy. 2013, Vol. 12, No. 1, s. 94-95; LEBZELTER, T. - MARX, A. Is EU GSP+ Fostering Good Governance? Results from a New GSP+ Compliance Index. Journal of World Trade. 2020, Vol. 54, No. 1, s. 18-20.

43 Usnesení Evropského parlamentu ze dne 16. března 2017 o Filipínách - př́ípad senátorky Leily M. De Limaové (2017/2597(RSP)), odst. 9.

44 Usnesení Evropského parlamentu ze dne 12. prosince 2018 o výroční zprávě o stavu lidských práv a demokracie ve světě v roce 2017 a o politice Evropské unie v této oblasti (2018/2098(INI)), odst. 51.

45 Usnesení Evropského parlamentu ze dne 14. března 2019 k provádění nařízení (EU) č. 978/2012 o systému všeobecných celních preferencí (2018/2107(INI)), odst. 4. Viz také PETRUCCI, F. - BOSSUYT, J. DE FEYTER, K. - FORESTI, M. - DOMINGO, O. - MONTI, S. Thematic Evaluation of the European Commission Support to Respect of Human Rights and Fundamental Freedoms (Including Solidarity with Victims of Repression): Final Report. Vol. 1, 2011, s. 25. 
a transparentních postupo̊ pro smysluplnou a posílenou účast nevládních organizací a o to, aby před udělením obchodních preferencí a během jejich uplatňování byla prováděna efektivní posouzení dopadu na lidská práva. ${ }^{46}$

Protože současné nařizení vyprší na konci roku 2023, aktuálně probíhá v EU veřejná konzultace, v níž mají přispěvatelé možnost vyjádřit se $\mathrm{k}$ fungování systému GSP a jeho budoucí úpravě. Podle prvotních úvah by nové nařízení GSP mělo začít platit od roku 2024 a lze předpokládat, že EP bude v rámci veřejné konzultace i následného legislativního procesu usilovat o silnější slovo při budoucím monitorování a provádění systému.

\section{ODPOVĚDNÉ OBCHODNÍ CHOVÁNÍ PODNIKU゚}

Poslední oblastí, která stojí za pozornost v souvislosti s lidskoprávní agendou Evropského parlamentu v obchodní politice, je odpovědné obchodní chování podniků (popř. byznys a lidská práva). Jedná se samozřejmě o téma, které bylo v minulosti opakovaně diskutováno na různých mezinárodních fórech, většinou s rozporuplnými výsledky. Proto byla také dosavadní pozornost Evropské unie soustředěna spíše na sektorové snahy o zlepšení situace.

Jednou z oblastí, kterými se Evropský parlament zabývá nejintenzivněji, je těžba cenných minerálů v konfliktních oblastech. Ve svých usneseních ze dne 7. ř́ijna 2010, 8. března 2011, 5. července 2011 a 26. února $2014^{47}$ EP opakovaně vyzýval k přijetí právních předpisů po vzoru zákona USA o konfliktních minerálech, známého jako oddíl 1502 Dodd-Frankova zákona o reformě finančních trhů a ochraně spotřebitele. I s pomocí tohoto soustavného tlaku bylo přijato nařízení Evropského parlamentu a Rady (EU) č. 2017/821 ze dne 17. května 2017, kterým se stanoví povinnosti náležité péče v dodavatelském řetězci pro unijní dovozce cenných nerostů. ${ }^{48}$ Jeho cílem je zavázat evropské společnosti k zodpovědnému získávání nerostných surovin z oblastí postižených konflikty, kde dochází k systematickému porušování lidských práv. ${ }^{49}$ Zvýšená kontrola obchodu s těmito surovinami by měla být také jedním ze způsobů, jak odstranit financování ozbrojených skupin, které přispívají k pretrvávající nestabilitě v zemích, odkud jsou suroviny dováženy. Zakotvena je také kontrolní role EP, nebot' Evropská

46 Usnesení Evropského parlamentu ze dne 12. prosince 2018 o výroční zprávě o stavu lidských práv a demokracie ve světě v roce 2017 a o politice Evropské unie v této oblasti (2018/2098(INI)), odst. 51.

47 Usnesení Evropského parlamentu ze dne 7. října 2010 o nedostatečné ochraně lidských práv a spravedlnosti v Demokratické republice Kongo, odst. 14; Usnesení Evropského parlamentu ze dne 8. března 2011 o daních a rozvoji - Spolupráce s rozvojovými zeměmi na podpoře řádné správy v daňové oblasti; Usnesení Evropského parlamentu ze dne 5. července 2011 o zvyšování dopadu rozvojové politiky EU; Usnesení Evropského parlamentu ze dne 26. února 2014 o podpoře rozvoje prostřednictvím odpovědných obchodních praktik, včetně úlohy těžebního průmyslu v rozvojových zemích.

48 Nařízení Evropského parlamentu a Rady (EU) č. 2017/821 ze dne 17. května 2017, kterým se stanoví povinnosti náležité péče $\mathrm{v}$ dodavatelském řetězci pro unijní dovozce cínu, tantalu a wolframu, jejich rud a zlata pocházejících z oblastí postižených konfliktem a vysoce rizikových oblastí.

49 V roce 2010 se konkrétně na Demokratickou republiku Kongo (DRK) a sousední země ve střední Africe zaměřila rezoluce Rady bezpečnosti OSN č. 1952, která vyzvala k dodržování zásad náležité péče v dodavatelském řetězci. 
komise by měla pravidelně podávat Evropskému parlamentu a Radě zprávy o účinnosti systému Unie stanoveného tímto nařízením. ${ }^{50}$

Dalším sektorem, kterému věnuje EP zvýšenou pozornost, je oděvní průmysl. V rámci globálních hodnotových řetězců v oděvnictví Evropský parlament podpořil Evropskou komisi v tom, aby prozkoumala možnost celounijní iniciativy pro oděvní průmysl stejně jako další cesty, jak zlepšit podmínky v tomto odvětví, zvláště co se týče ochrany zdraví, životního minima, svobody sdružování a kolektivního vyjednávání, prevence sexuálního obtěžování a násilí na pracovišti nebo odstranění nucené a dětské práce. Zdůraznil přitom, že hlavní zásadou legislativního návrhu EK by měly být nově připravené pokyny Organizace pro hospodářskou spolupráci a rozvoj (OECD) pro náležitou péči v zodpovědných dodavatelských řetězcích v oděvním a obuvnickém průmyslu. ${ }^{51}$

$\mathrm{V}$ poslední době se aktivita EP projevuje s ohledem na diskuze $\mathrm{k}$ právně závaznému nástroji, který by upravoval činnost nadnárodních společností a dalších podniků z hlediska lidských práv. Od července 2015 zasedá v Ženevě otevřená mezivládní pracovní skupina pro vypracování takového nástroje. ${ }^{52}$ Unijní prístup zůstává od počátku rezervovaný a Rada, Evropská komise ani jednotlivé členské státy prozatím př́liš nadšení vůči návrhu závazného nástroje neprojevily. Podle zdrženlivé odpovědi vysoké představitelky Unie pro zahraniční věci a bezpečnostní politiku Federicy Mogheriniové na interpelaci v EP je zásadní, aby jakýkoli budoucí mezinárodní rámec byl založen na Obecných principech OSN pro byznys a lidská práva z roku 2011.53 Evropský parlament se však staví do role silného podporovatele této iniciativy a požaduje, aby se Unie aktivně a konstruktivně do diskuzí zapojila. ${ }^{54}$ I zde tak může dojít pod vlivem EP k postupné změně unijní pozice.

\section{ZÁVĚR}

Lisabonská smlouva významně posílila postavení Evropského parlamentu ve společné obchodní politice Unie, který tak uplatňuje na její podobu bezprecedentní vliv. To se v praxi projevuje i v prosazování lidskoprávní dimenze obchodní politiky, která se dříve soustř̌ed’ovala pouze na „komerční“ otázky. Zůstává však také patrný rozdílný př́stup jednotlivých unijních institucí. Zatímco Evropský parlament prosazuje přísnější přístup, např. $v$ rychlejším a častějším pozastavování výhod třetím zemím, Rada a Evropská komise se spoléhají na nástroje „pozitivní motivace“, kdy jsou obchodněpolitické nástroje používány k podpoře lidských práv cestou vidiny při-

50 Nařízení Evropského parlamentu a Rady (EU) č. 2017/821, čl. 17 odst. 2.

51 Usnesení Evropského parlamentu ze dne 27. dubna 2017 o stěžejní iniciativě EU pro oděvní průmysl (2016/2140(INI)), odst. 4, 6.

52 Rezoluce Rady OSN pro lidská práva č. 26/9 ze dne 26. června 2014.

53 Evropský parlament. Answer given by Vice-President Mogherini on behalf of the Commission, P-005597/2017, 27. ř́jna 2017.

54 Usnesení Evropského parlamentu ze dne 21. ledna 2016 o prioritách EU pro zasedání Rady OSN pro lidská práva v roce 2016 (2015/3035(RSP)), odst. 28; Usnesení Evropského parlamentu ze dne 4. října 2018 o prííspěvku EU k závaznému nástroji OSN, který by upravoval činnost nadnárodních společností a dalších podniků z hlediska lidských práv (2018/2763(RSP)). 
slíbení výhod spíše než pod hrozbou sankcí..$^{55}$ Svoji roli pak jistě hraje i fakt, že Rada a Evropská komise jsou v prímém politickém kontaktu se třetími zeměmi a mohou lépe zhodnotit reálnou situaci a možnosti jejího zlepšení.

Uplatňování lidskoprávní agendy EP lze pozorovat v několika oblastech. Evropský parlament se snaží ovlivňovat obsah obchodních a investičních dohod sjednávaných Unií, aby zohledňovaly a podporovaly lidská práva, at' už ve formě doložky o lidských právech, nebo komplexnějšími kapitolami o udržitelném rozvoji. Tomu výrazně napomáhá jeho právo veta nad všemi mezinárodními smlouvami, které EU zamýšlí uzavřít. Za problém se ale považuje nadále fakt, že je-li souhlas s dohodou vysloven, EP už nemá žádné prímé nástroje, jak dohlížet na naplňování př́slušných klauzulí, a je omezen na usnesení adresovaná Evropské komisi a Radě. Dohoda může být navíc prozatímně prováděna ještě předtím, než s ní EP vysloví souhlas.

Vedle mezinárodních dohod je dalším důležitým nástrojem GSP. V tomto př́ípadě EP volá po jeho důslednějším uplatňování ve vztahu k ochraně lidských práv. Nicméně i v tomto případě má ústřední roli v provádění Komise a EP vykonává spíše nepř́mý vliv. Ve výčtu nesmí chybět ani odpovědné obchodní chování podniků. EP zaznamenal $\mathrm{v}$ této oblasti výrazné úspěchy, kdy se i s jeho aktivní podporou podařilo schválit nařízení, kterým se stanoví povinnosti náležité péče $\mathrm{v}$ dodavatelském řetězci pro unijní dovozce cenných nerostů, a v různé fázi rozpracovanosti jsou další sektorové iniciativy. Postoj EU k právně závaznému nástroji pro nadnárodní společnosti a další podniky z hlediska lidských práv zůstává nevyjasněný, nicméně pozitivní postoj EP bude mít významný vliv na další diskuze uvnitř EU a může vést $\mathrm{k}$ rostoucímu zapojení EU a změně původně skeptického postoje.

Lze uzavřít, že Evropský parlament se od přijetí Lisabonské smlouvy stal významným aktérem $\mathrm{v}$ tvorbě společné obchodní politiky a tento vývoj zapadá do obecnějšího trendu „parlamentarizace“ zahraniční politiky. ${ }^{56}$ Nově nabytý vliv pak EP v praxi mj. uplatňuje $\mathrm{v}$ důslednějším prosazování dodržování lidských práv $\mathrm{v}$ zahraničí prostřednictvím obchodněpolitických nástrojů EU. Výhledově lze očekávat, že jeho role bude $\mathrm{v}$ této oblasti nadále posilovat.

Mgr. Bc. Ondřej Svoboda, Ph.D.

Právnická fakulta Univerzity Karlovy

svobodao@prf.cuni.cz

55 PETRUCCI - BOSSUYT - DE FEYTER - FORESTI - DOMINGO - MONTI, c. d., s. 18.

56 RAUNIO, T. - WAGNER, W. Towards parliamentarisation of foreign and security policy?. West European Politics. 2017, Vol. 40, No. 1, s. 1-19. 